\title{
燕尾椂椎弓を呈した腰部脊柱管狭窄症の手術例の検討
}

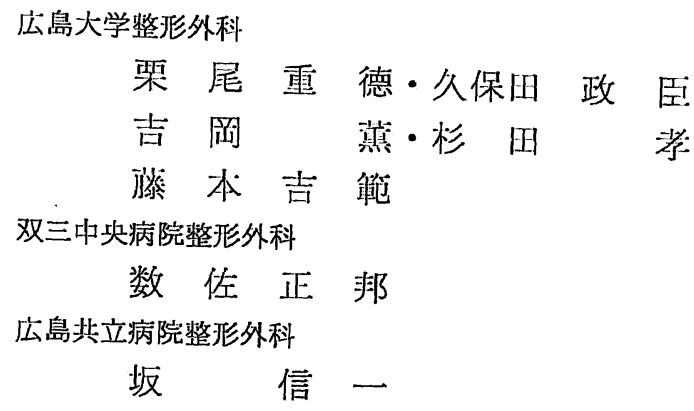

\section{Four Cases of Lumbar Canal Stenosis associated with the Swallow-tail Shape of Lamina}

by

Shigenori Kurio, Masaomi Kubota, Kaoru Yoshioka, Takashi Sugita and Yoshinori Fujimoto

Department of Orthopedic Surgery, Hiroshima University.

Masakuni Kazusa

Department of Orthopedic Surgery, Futamichuo Hospital.

Shinichi Saka

Department of Orthopedic Surgery, Hiroshima-Kyoritsu Hospital.

We reported Four cases of lumbar canal stenosis associated with the swallow-tail shape of the inferior articular process which was seen on the P-A view of a roentgenography.

We described three mechanisms in the development of the lumban canal stenosis associated with the swallow-tail shape of the lamina. We also referred the method of the operation.

\section{はじめに}

腰部 脊柱管 狄窄症 は, Verbiest'17) が 1954 年に developmental stenosis の症例を発表して以来注 目されるようになり，本邦においてす1970年若松18) の報告以来多〈の報告がある. 1976 年国分5〉 は，単 純X線前後像で，下関節突起が長くしかむそれが内側 下方に伸びて鋭となり，椎弓間涳を両側から狭めて， 燕の尾に思わす特異な形態をした椎弓を燕尾様椎弓と 表現し，脊柱管狭小発生の developmental な要素之 考えられると報告した. 私達も炤和 55 年以来, 腰部 脊窄症の手術は 38 症例に施行し，うち 4 例の燕尾 様
椎弓例を経験したので文献的考察を加えて報告する．

症例

症例の内訳は表 1 亿示す通りで全例男性で，手術洔 平均年齢は 53 歳であった。臨床症状について検討す る之間歇跛行は全例にみられ跛行発現距離は平均 120 $\mathrm{m}$ 之極めて短距離であった．また通常の春柱管狭窄症 では比較的頻度が少ないと言われている膀胱直腸障害 も2例 (50\%) に認められた.一方他覚所見では，筋 力低下や筋萎縮が全例にあった，次に代表症例を示 于.

症例 259 歳男性 昭和 40 年頃より長途歩行にて存 
表 1 说: 例

\begin{tabular}{|c|c|c|c|c|c|c|c|c|c|c|c|c|c|c|}
\hline \multirow[b]{2}{*}{ 证: 例 } & \multirow{2}{*}{ 年:令 } & \multirow[b]{2}{*}{ 性: } & \multirow{2}{*}{\multicolumn{2}{|c|}{ 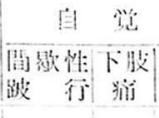 }} & \multirow{2}{*}{ 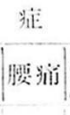 } & \multirow{2}{*}{ 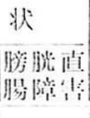 } & \multicolumn{3}{|c|}{ 他觉所塄 } & \multicolumn{2}{|c|}{ 》! 純 X 線 } & \multicolumn{2}{|c|}{ ミエログラム } & \multirow[b]{2}{*}{ 椎弓切除籍四十 } \\
\hline & & & & & & & $\left|\begin{array}{cc}\text { Laségue } \\
\text { 微 } & \text { 佔 }\end{array}\right|$ & 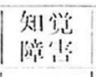 & 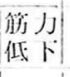 & $\begin{array}{l}\text { 燕厄橧 } \\
\text { 椎 }\end{array}$ & $|i \cdot b|$ & 䧑然部位: & 形 & \\
\hline 1 & 52 & 93 & $200 \mathrm{~m}$ & - & + & + & - & \begin{tabular}{|l|} 
沙侧 \\
低下
\end{tabular} & + & $\mathrm{L}_{1} \sim \mathrm{L}_{5}$ & + & $\mathrm{L}_{4-5}$ & 完 金 & $\mathrm{L}_{4}$ \\
\hline 2 & 59 & 早 & $120 \mathrm{~m}$ & + & + & - & - & " & + & $\mathrm{L}_{2} \sim \mathrm{L}_{5}$ & + & $\begin{array}{l}\mathrm{I}_{1-5} \\
\left(\mathrm{~L}_{5-6}\right)\end{array}$ & " & $\mathrm{L}_{(4), 5 .(6)}$ \\
\hline 3 & 49 & 男 & $50 \mathrm{~m}$ & - & + & - & - & 们消失 & + & $\mathrm{L}_{2} \sim \mathrm{L}_{4}$ & - & $\begin{array}{l}\mathrm{L}_{3-4} \\
\left(\mathrm{~L}_{4-5}\right)\end{array}$ & " & $\mathrm{L}_{(3), 4,(5)}$ \\
\hline 4 & 51 & 男 & $100 \mathrm{~m}$ & + & + & + & - & $\begin{array}{l}\text { 监栰 } \\
\text { 消失 }\end{array}$ & + & $\mathrm{L}_{1} \sim \mathrm{L}_{4}$ & - & $\begin{array}{l}\mathrm{L}_{2-3} \mathrm{~L}_{3-4} \\
\mathrm{~L}_{4-5} \mathrm{~L}_{5-} \mathrm{S}_{1}\end{array}$ & $\begin{array}{l}\text { 不完 全 } \\
\text { ブロック }\end{array}$ & $\mathrm{L}_{4,5 .}\left(\mathrm{S}_{1}\right)$ \\
\hline
\end{tabular}

*（）内の部位は不完全ブロックの部位を示す。十（）は部分椎马切除を意味する.

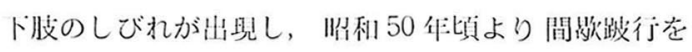
呈するようになった。顺和 57 作 8 月に当科党受新し

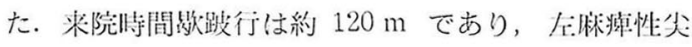
足も認好た．理学所胃では知觉障害や Laségue 徽侯 はなかったがアキレス腱反射は雨側低下していた。単 純 $\mathrm{X}$ 線では, 前後像にて $\mathrm{L}_{2}$ より $\mathrm{L}_{5}$ までに燕尾様椎 弓をみとめ，側面像では $\mathrm{L}_{5}$ の前方司りがあった： エログラムでは $\mathrm{L}_{4-5}, \mathrm{~L}_{5-6}$ 間にブロック像を綛めた。

(図1) 昭和 53 年 10 月 $\mathrm{L}_{5}$ の椎弓切除術之 $\mathrm{L}_{4}, \mathrm{~L}_{6}$ の部分椎弓切除術を施行した. 術後 1 年の見在, 間歇 跛行は消失した日趾の背屈す可能となっている.

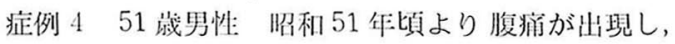
炤和 55 年頃より右下肢のしびれと間歇跛行が出現す るようになり炤和 57 年 4 月当科索受彰した。来院時 には，間歇跛行は約 $100 \mathrm{~m}$ で膀胱直腸障害む認め た. 理学所見では両倒のアキレス腱反射の消失之, 右 下肢知覚障害および觔萎縮と觔力低下を垫めた．X線 像では， $\mathrm{L}_{1}$ より $\mathrm{L}_{4}$ に燕尾様椎弓をみとめ，惟弓間 腔は燕尾㥞椎弓により狄められていた。 ミエログラム では, $\mathrm{L}_{2-3}, \mathrm{~L}_{3-4}, \mathrm{~L}_{4-5}, \mathrm{~L}_{5}-\mathrm{S}_{1}$ 間で仯時計様の絞抳が みら机た（図 2 )。昭和 57 年 4 月に $\mathrm{L}_{4}, \mathrm{~L}_{5}$ の椎弓切 除術と $S_{1}$ の部分椎弓切除術を施行した。術中所見で は，雨側の椎間関節焱起は，正中に近接しており硬膜 はその近接した椎問関節により後倒方から压迫されて いた. 術後 1 年半の現在, 間题跛行, 腰为, 下肢のし びれ感，膀腅直腸障害屯全く消失している.

$$
\text { 考察 }
$$

燕尾様椎弓と腰部脊柱管狭窄症との関係について

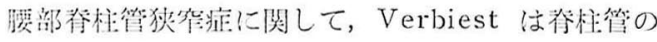
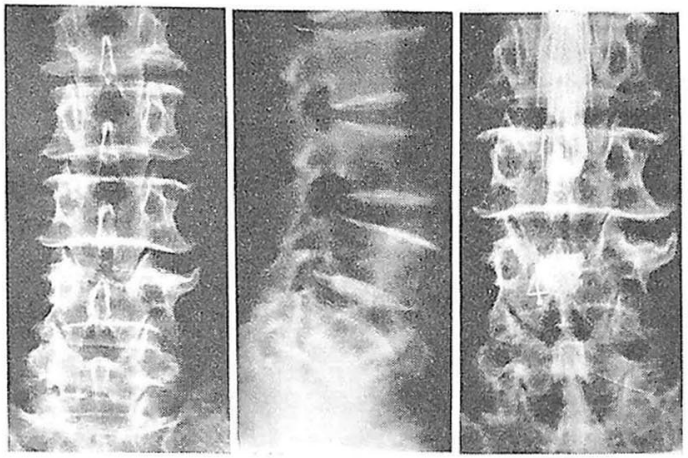

図 1 症例 2 59才男性

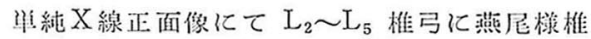
马を涊める。侧面像では $\mathrm{L}_{5}$ の前方沪りを認 める.
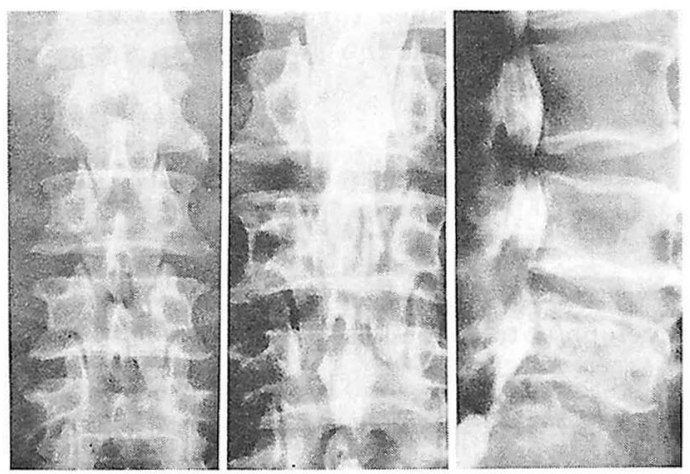

図 2 症例 4 51才男性

当純線正面像にて $\mathrm{L}_{1 \sim 1}$ 椎弓に燕尼橙椎弓を 热める.

前後径に注目し, Epstein ${ }^{1)}$ はさらに lateral recess の狄小化を強調した。一方若松らは lateral recess 


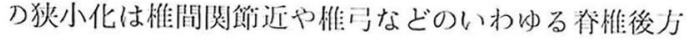
要素での spondylosis による肖变化に一玟すると述

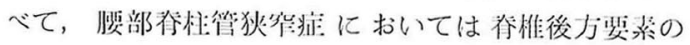
levelopmental な裂因 と spondylotic な要因が考

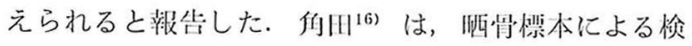

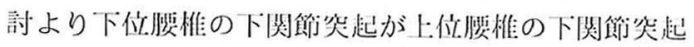
の形態を有するものに食柱管狄窄症が多いと述べた. また国分は燕尾㥞惟弓が耐忹:管狄窄症の一要因になる と報告し，燕尾棁惟弓が答柱:管狄帘を来たす機序とし て, 第 1 に燕尾㥞椎弓では下阅䬦突起が正中に近挍し ており，乙れに刘応して上関節然起む後倒方より空出 し，椎管の横断面が trefoli 型となるた教枉管狄窄 症をきたすと述べた、第 2 亿燕尾様椎弓では, 椎間関 䬦の方向が前額面に対して vertical でかつ尾侧ほど 内側に向ってすぼんで书り，てのため mechanical な弱点を有し，过りを生じやすくその絬果脊柱管狄害 をおこすと述べた，自験例における CT 像の検討で 屯図 3 に示す如く, 燕尾粶椎弓例では関䬣突起の正中 への近接の程度が他の奉柱管狄窄症例に比べて強いて とが水かる。また第 2 点に関しても自験例の半数に之 り症老認. 以上の如く, 国分は燕尾様惟弓による 椎管狄小の発生に関して $2 つ の$ 機序を举げたが, さら に第 3 の機序として, vertical な椎間関節それ自体 が奉柱管狄窄症の要因になりえると考元られる。本強 矢 ${ }^{8)}$ は, 脊椎管の後倒方汃らの突出には, 矢状型関鸰 すなわち椎間関節が前額面に刘して vertical なあの が重要な役割をもっており, 病理組織学的検索でも矢 状型椎間関節では, 強い変性がみられたと述べている. 燕尾様椎弓は, 全例矢状型椎間関節であるため, 後側 方よりの狭窄の成因となりえると考える．以上より燕 尾様椎弓は, 脊忹管狄害症の要因之考元ら机るため, 単純 $\mathrm{X}$ 線でこのような形態の椎弓を認めた場合には膜 部春柱管狄窄症を念頭におく必要があると思われる。

\section{術式について}

燕尾様椎弓を呈した渴部脊柱管狄窄症では前述の如 く, 燕尾様椎弓の形態的特徵, すなわち椎間関節が前 額面に対して vertical であるため，馬尾神経および 神経根に対して光分な除圧を行なうとすると椎間関節 に加わる侵箦がしばしば大となり, 術後の金柱不安定 性発現につながる.そこで私暹は，て机に刘処すべく できる限り椎間関節を温存し，しかも馬尾神経ならび に神経根に対する除圧を充分に得るため, oblieque
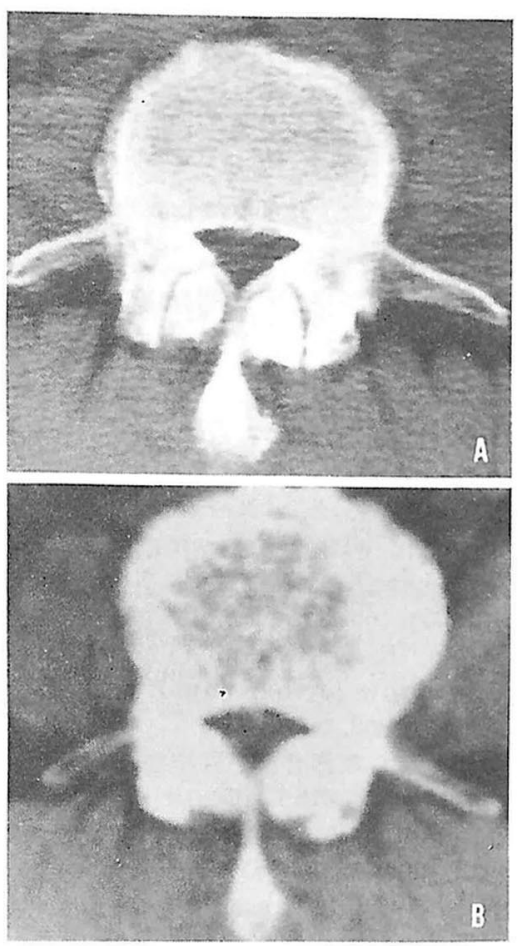

図 3

A 症例 1, B 快症例 2 の CT 像である.

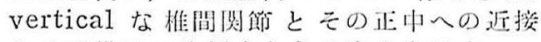
および椎弓の後側方からの突仴を示す。

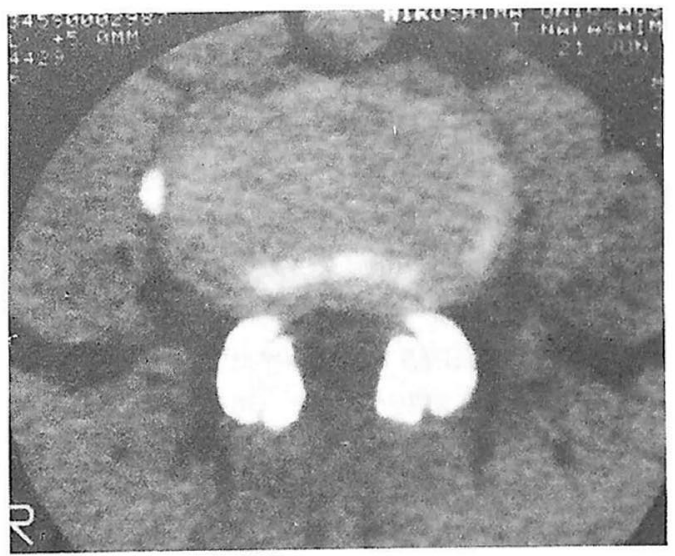

図4 症例 451 男珄 oblieque osteotomy 後の CT 像 下関節突起がよく温存されている.

osteotomy 在行なっている(図 4). との際, 無偟 性の手術を行ないしかも不必要な骨切除を防ぐために は, air tome の使用が不可火であると考える. 


$$
\text { ま と め }
$$

1. 燕尾様椎弓を呈した腰部脊柱管狄窄症の 4 例を 報告した.

2. 燕尾様椎弓は, 腰部脊柱管狄窄症の要因となり えると推测される。

3. 燕尾様椎弓を呈した腰部脊柱管狭窄症の手術方 法についても言及した.

\section{文献}

1) Epstein, J. A. : Nerveroot compression associated with narrowing of the lumbar spinal canal. J. Neural, Neurosurg. Psychat. 25: 165-176, 1962.

2) Jones, R. A. C. and Thomson, J. G.: The narrow lumber canal. J.B.J.S. $50 \mathrm{~B}$ : 595-612, 1968.

3）片岡 治: 腰部脊椎管狭窄症の Myelography. 整外. 25：801-815. 1974.

4）河合伸也：腰部脊柱管狭窄症の臨床症状。整 外, 32: 720-726. 1981.

5) 国分正一: Lumbar spinal stenosis 臨整外, 11: 852-855, 1976.

6）喿原 章：腰部脊椎管狭窄症の定義と分類につ いて. 臨整外, 11: 734-739, 1976.

7）円尼宗司：腰椎椎管の狭窄に対する検討. 整 外, 25: 755-764, 1974.

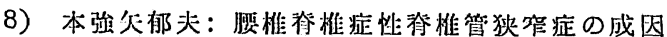

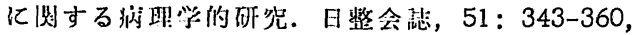
1977.

9) Naylor: Factors in the development of the spinal stenosis syndrome. J. B. J. S. $61 \mathrm{~B}:$ 306-309, 1979.

10) Postachini : Computerised tomography in lumbar stenosis. J. B. J. S. 62 B: 72-82, 1980.

11）佐藤光三：腰部脊椎管狭窄症とその手術成緽. 整整外，11：172-179，1976.

12）占崎㹂一：腰部脊椎管狭窄症の $\mathrm{X}$ 線钐断. 整 外, 32: 743-748, 1981.

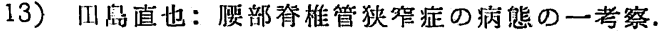
整形災㫮外科，23：1513-1519，1980。

14）辻 陽焳：腰部脊柱管 $\mathrm{X}$ 線計測法の再検討. 臨 整外. 11: 10-17, 1976.

15）辻 陽雄：腰部脊柱管狭窄症. 臨整外， 16: $598-612,1981$.

16）角田信昭：屍体晒骨標本による腰部脊柱管の形 態学的研労. 臨整外, 11：677-685, 1976.

17) Verbiest: A radicular syndrome from developmental narrowing of the lumbar vertebral canal. J. B. J. S. 36 B. 230-237, 1954.

18）若松英告：Lumbar spinal stenosis につい て. 整外, 21: 1-7, 1970 .

19）若松英占：腰部脊柱管㹟窄症。整外，30：477485, 1979. 